\title{
Employer brand equity effects on employees well-being and loyalty
}

\author{
Laïla Benraiss-Noailles \\ Associate Professor \\ IRGO \\ Institut d'Administration des Entreprises, Université de Bordeaux \\ 35 avenue Abadie \\ 33072 Bordeaux Cedex \\ France (+33) 556009702 \\ laila.benraiss-noailles@u-bordeaux.fr
}

To cite this paper:

Benraïss-Noailles L., Viot C. (2020), Employer brand equity effects on employees well-being and loyalty, Journal of Business Research, in press, https://doi.org/10.1016/j.jbusres.2020.02.002

Available online 17 February 2020.

\author{
Catherine Viot $^{1}$ \\ Full Professor \\ Laboratoire de Sciences Actuarielle et Financière - Université de Lyon \\ 50 Avenue Tony Garnier \\ 69366 Lyon Cedex 07 \\ France (+33) 610185227 \\ catherine.viot@univ-lyon1.fr
}

\section{Acknowledgements}

The authors would like to thank the reviewers and the associate guest editors for their careful readings, valuable feedback and recommendations as well as William Sabadie and Maud Damperat for supporting this study in providing assistance for data analyses.

\footnotetext{
${ }^{1}$ Corresponding author
} 


\section{Effects of employer brand equity on employee well-being and loyalty}

\section{Abstract}

This study questions the relevance of Berthon, Ewing and Hah's (2005) employer brand equity (EmpAt) scale, which measures five dimensions of employer attractiveness: economic value, interest value, social value, development value, and application value. Therefore, replication is necessary, from a theoretical perspective, to corroborate the five-factor structure and the external validity of the EmpAt scale and, from a managerial perspective, to provide empirical evidence of the managerial usefulness of the scale.

The purpose of this research is two-fold: first, to question the relevance of this measurement tool; and second, to examine its explanatory power.

An online survey of 604 employees reveals that this scale needs some adjustment, although the structure of the scale seems to be reliable overall. The results also highlight the effects of employer brand equity on positive employee well-being, which in turn, influences loyalty.

Keywords

Employer brand - Well-being - Loyalty - Scale replication

This research did not receive any specific grant from funding agencies in the public, commercial, or not-for-profit sectors. 


\section{Introduction}

For decades, studies have emphasized the lack of replication research in marketing (Hubbard \& Amstrong, 1994; Evanschitzky \& Armstrong, 2013). Despite repeated calls for replication research, marketing studies corroborating previous results remain rare. In response to this need for research replication, this paper intends to retest the relevance of the EmpAt (employer attractiveness) scale (Berthon, Ewing, \& Hah, 2005) in measuring employer brand equity (EBE). This replication pertains to the scope of human-resource (HR) marketing, which is of growing interest to both practitioners and researchers due to the difficulty employers experience in attracting and retaining talent with certain profiles. The term "consumption" covers a wide range of situations and, according to current thinking in HR marketing, we can consider the employee to be the client, the employer the brand, and HR the supplier of the product (Panczuk \& Point, 2011). The employer brand concept is a perfect illustration of the combination of marketing and HR. This concept has prompted numerous publications since the mid-1990s and continues to do so (Kima, Jeon, Jung, Lub, \& Jones, 2011; Liua, Ko, \& Chapleo, 2017).

While academics generally agree that Ambler and Barrow's paper (1996) is the starting point for the scientific infatuation with the concept of employer brand, Berthon, Ewing and Hah's publication (2005) is recognized as the equivalent to Ambler and Barrow's paper, as far as EBE measurement is concerned. The concept of employer brand, defined as "the package of functional, economic and psychological benefits provided by employment and identified with the employing company" (Ambler \& Barrow, 1996, p. 187), still receives attention from both practitioners and researchers in HR marketing.

Our study questions the relevance of the Berthon et al. (2005) EBE scale, better known as the EmpAt scale. In their seminal paper, Berthon et al. showed that EBE is a multidimensional 
construct reflecting five types of values provided to "HR customers" and characterizing the employer brand: economic value (e.g., salary), interest value (e.g., interesting work), social value (e.g., an enjoyable working environment), development value (e.g., advancement opportunities), and application value (e.g., opportunities to implement one's own knowledge). Since its publication, this paper has been quoted often (Arachchige \& Robertson, 2011; Biswas \& Suar, 2016; Jiang \& Iles, 2011; Lee, Kao, \& Lin, 2018; Roy, 2008; Sharma \& Prasad, 2018).

The arguments in favor of replicating Berthon's study are strong. First, the authors developed their scale 15 years ago, and consumers' expectations have changed since the mid-2000s: the benefits consumers hope to gain from consumption and brand choice have evolved (Soulez \& Guillot-Soulez, 2011); we can also observe this change in expectations among employees. Even the youngest generations of workers (Gen Z and Gen Y) express different expectations. Young people from Gen $\mathrm{Z}$ "would rather have a job that offers financial stability than one that they enjoy", whereas millennials "generally prioritize finding a job that is more fulfilling over one that simply pays the bills" (Miller, 2018). Second, the EmpAt scale was initially used as a tool for evaluating the (external) attractiveness of the employer brand. Our aim is to show that this tool is also well suited for talent retention. Third, the EmpAt scale lacks external validity: to develop their scale, Berthon et al. (2005) used a convenient sample of undergraduate students (683 respondents). Our sample is composed of 604 French employees from varied industries. Last, in their pioneering paper, Berthon et al. (2005) did not provide evidence of their EBE scale's explanatory power. We go further by linking EBE and loyalty. We assume that the influence of EBE on loyalty is indirect and mediated by employee well-being. Therefore, replication is necessary from, a theoretical perspective, to corroborate the five-factor structure 
and the external validity of the EmpAt scale and, from a managerial perspective, to provide empirical evidence of the managerial usefulness of the scale.

The structure of the rest of the paper is as follows. The first part deals with the concept of EBE. Next, an online survey empirically tests the EBE structure and explanatory power. A discussion of the results follows.

\section{Theoretical framework: from employer brand to EBE}

Since the mid-1990s and the pioneering paper by Ambler and Barrow (1996), the employer brand concept has received increasing academic and managerial interest. The employer brand is now considered to be a unique value proposition (Ewing, Pitt, de Bussy, \& Berthon, 2002; Franca \& Pahor, 2012) defining what a given employer brand delivers to its HR targets compared with other employer brands in the marketplace.

More recently, the focus has shifted from employer brand to EBE. EBE is more than employer brand because EBE refers to employer brand strengths and value (Franca \& Pahor, 2012). In marketing, Aaker (1991) defined brand equity in terms of the value provided to customers. In accord with Aaker's definition of brand equity, Ewing et al. (2002) assumed that EBE is a set of assets and liabilities linked to a firm brand (the name and symbol of the firm); these assets and liabilities add to (or subtract from) the value that the firm provides for its current and potential employees.

EBE reflects both the internal and external value resulting from management of the employer brand (Foster, Punjaisri, \& Cheng, 2010). In the HR context, most EBE publications choose a perceptual approach to EBE; Keller (1993) has advocated this approach in marketing. 
In addition to carrying out a single replication study, the aim of this research is to strengthen the predictive validity of the EmpAt scale. Therefore, we propose a conceptual model that includes well-being, which is a construct of major interest to marketers and employers.

\section{Conceptual model and hypotheses}

The focus of this research is to retest the reliability and internal validity of the EmpAt scale and to assert the predictive validity of the scale by proposing a causal model integrating employee well-being and loyalty (Figure 1).

Insert Figure 1 about here ------

\subsection{Effects of EBE on employee well-being}

Well-being, a positive psychological state that stems from an individual's life perception and evaluation, has attracted considerable interest recently among both practitioners and researchers. Well-being, a multifaceted construct encompassing physical, intellectual, collective and material well-being, usually concerns happiness and quality of life (Gorge, Özçaglar-Toulouse, \& Toussaint, 2015, p. 105).

Research connecting EBE and employee well-being is apparently rare (Authors, 2019). In the marketing field, however, the relationship between brand and consumer well-being is an issue that has recently generated some interesting literature. Aureliano-Silva, Strehlaub, and Strehlaub (2018) showed that brand attachment is positively linked to consumer well-being. Troebs, Wagner, and Heideman (2018) demonstrated that transformative brands positively influence consumer well-being. Similarly, we consider that EBE and employee well-being are linked. Given that well-being is a two-dimensional construct consisting of a negative and positive dimension (Warr, 1990), the effects of EBE differ according to whether positive or negative 
well-being is considered. We consequently expect the relationship between EBE and positive well-being to be positive, while we expect the relationship between EBE and negative well-being to be negative.

H1. EBE is positively linked to positive well-being (H1a), while EBE is negatively linked to negative well-being (H1b).

\subsection{Effects of EBE on employee loyalty}

Oliver (1999: p. 34) defined customer loyalty as "a deeply held commitment to rebuy or repatronize a preferred product/service consistently in the future, thereby causing repetitive same-brand or same-brand set purchasing, despite situational influences and marketing efforts having the potential to cause switching behaviors". Following this marketing definition, employee loyalty is "a strong tie that binds an employee to his/her company even when it may not be economically sound for him/her to stay there" (Logan, 1984). People stay because of their positive affect and feelings about their organization (Mitchell \& Lee, 2001). Loyalty thus corresponds to a relationship of trust provoking resistance to the adoption of opportunistic behavior as a consequence of external job offers. For this reason, researchers often measure employee loyalty in terms of intention to leave.

Most companies face staff turnover, which reached $15.1 \%$ in France in $2018 .^{2}$ While retention of all employees can hinder skills renewal, turnover becomes a major problem when turnover affects skilled employees. The cost to companies of skilled employee turnover has been estimated to be between 1.5 and 2.5 times the departing employee's annual salary (Wright \& Bonett, 2007).

\footnotetext{
${ }^{2}$ Kelly Services Survey (acceded January 2020): http://www.kellyservices.fr/uploadedFiles/Dev_Kelly_Services(1)/rapport \%20KGWI\%20n\%C2\%B01.pdf,
} 
A recent survey of 14,000 French employees shows that $32 \%$ intend to leave their employer. ${ }^{3}$ Intention to leave is a subjective assessment of the probability of leaving the current job in the near future (Mowday, Porter, \& Steers, 1982) or a conscious desire, a deliberate intention, to leave one's job (Cho, Johanson, \& Guchait, 2009). Some authors see an intention to leave as the final step in a phase of reflection whose purpose is to weigh the pros and cons of leaving a current job (Bigliardi, Petroni, \& Ivo Dormio, 2005), while others consider that an intention to leave may arise from an isolated event (Morrell, 2005). Giraud (2015) considered an intention to leave to be the best indicator of the adoption of an actual departure behavior (Giraud, 2015), as this intention reflects an employee's desire to leave his/her employer voluntarily (Moore, 2000). In marketing, brand equity influences attitudinal and behavioral customer loyalty (Taylor, Celuch, \& Goodwin, 2004). Given that we measured employee loyalty by a negative behavioral intention, we expect the influence of EBE on intention to leave to be negative.

H2. EBE is negatively linked to intention to leave.

\subsection{Effects of well-being on employee loyalty}

In the early 1930s, Fisher and Hanna (1931) emphasized the effects of well-being on different employee attitudes: employee withdrawal, propensity to be absent, and contribution to the company's results (cited by Wright \& Bonett, 2007, p. 144). Employees with low levels of wellbeing at work were more likely to leave their employer (Wright \& Bonett, 2007).

H3. Well-being at work influences the intention to leave an employer. The influence of positive well-being on intention to leave is negative (H3a), whereas negative well-being has a positive influence on intention to leave (H3b).

\section{Methodology}

\section{${ }^{3}$ Ibid}




\subsection{Sample}

We invited approximately 8,000 individuals employed by companies registered with the Chamber of Commerce and Industry of Nouvelle Aquitaine to answer an online survey. This region of France represents $9 \%$ of the country's total population. In total, 842 people responded to the survey (thus, producing a response rate of 10.3\%). After eliminating temporary employees, trainees, job seekers and business owners, we analyzed 604 questionnaires; 58\% of the respondents are men, and $85.5 \%$ of the respondents are employed in private companies $(91 \%$ are on permanent contract). The $46-55$ age class (33.5\% of the respondents) is the largest in the sample; those aged 25-35 and 36-45 represent $25.3 \%$ and $26.8 \%$, respectively, of the respondents. Seniors (aged over 55) and younger workers (aged under 25) represent 8.6\% and $5.8 \%$, respectively, of the sample; thus, these respondents are the least represented. In total, 57\% of the respondents are graduates of higher education (i.e., they have a bachelor's or master's degree); this percentage is high when compared with national statistics. In France, the proportion of people with a higher education qualification is $43 \%$ for people between 25 and 29 years old and $29.8 \%$ for people aged between 25 and $64 .^{4}$

\subsection{Measurement scales}

We used scales that have already been published (Table 1): the EmpAt 25-item scale (for EBE) and Warr's (1990) 12-item scale (six positive and six negative), which is designed to measure well-being both at and outside work. In the work-related version of Warr's scale, we asked the respondents to assess how often (from 'never' to 'always') they had experienced certain feelings over the previous two weeks. Finally, we measured intention to leave, which is considered to be

\footnotetext{
${ }^{4}$ Source: media.enseignementsup-recherche.gouv.fr (acceded January 2020): https://publication.enseignementsuprecherche.gouv.fr/eesr/7/EESR7 ES_19-le_niveau_d_etudes_de_la_population_et_des_jeunes.php
} 
the best indicator for the adoption of obvious withdrawal behavior (Giraud, 2015), by using a 4item scale (Moore, 2000).

\section{Results}

\subsection{Measurement model}

First, we carried out a principal component analysis that confirmed the 5-factor structure of the EmpAt initial scale. ${ }^{5}$ However, we had to remove 7 items because they correlated with more than one factor or had poor communality, or both. As the data originate from the same respondents, we ran a post hoc common bias variance test. Harman's one-factor test is the most frequently used in the JBR and can "detect biasing levels of common variance under conditions commonly found in survey-based marketing research" (Fuller et al., 2016, p. 3197). The first principal component accounted for $19.45 \%$ of the variance; this percentage is well below the recommended cutoff of 50\% (Podsakoff \& Organ, 1986).

Next, we used structural equation modeling (AMOS 25 with a maximum likelihood method) to confirm the structure of all scales. We eliminated two additional items to improve the goodness of fit $(\mathrm{GOF})$ indices: RMSEA $=0.073 ; \mathrm{CFI}=0.923 ; \chi 2=399 ; \mathrm{df}=94 ;$ and $\mathrm{p}<0.001 .{ }^{6} \mathrm{We}$ applied a bootstrap $(\mathrm{N}=200)$ to determine a confidence interval and the statistical significance of the estimated parameters (Table 1). The values of the GOF indices were within the optimum norms defined by Hair, Babin, and Krey (2017). The values of Jöreskog's rho varies from 0.74 to 0.85 , thereby demonstrating good reliability.

------ Insert Table 1 about here ------

\footnotetext{
${ }^{5}$ The results of the PCA are not reported in this paper because our research is confirmatory. KMO $(0.845)$ and Bartlett tests $(\chi 2=4627$; $\mathrm{df}=153 ; \mathrm{p}<0.001)$ confirm that a PCA can be run.

${ }^{6}$ For EBE3 and EBE20, RMSEA $=0.089 ; \mathrm{CFI}=0.870 ; \chi 2=715 ; \mathrm{df}=125$; and $\mathrm{p}<0.001$ )
} 
We also checked the reliability, convergent validity and discriminant validity of EBE (Table 2) and other constructs (Table 1). Except for the application value, the average variance extracted (Fornell \& Larcker, 1981) was greater than 0.5 . We also established the discriminant validity of each latent construct (Anderson \& Gerbing, 1988). The means, standard deviations and correlations for all items are reported in Appendix A. In addition, Table 3 reports the means scores for each construct.

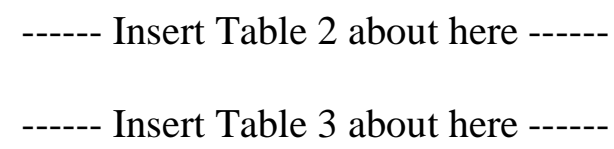

Berthon's scale presents good psychometric characteristics as a measurement tool, but this result must be tempered given the necessary adjustments discussed later.

\subsection{The predictive validity of the EmpAt scale}

We tested the predictive validity of the EmpAt scale by using the same SEM method. In this model, EBE is considered to be a second-order factor. The AVE for the higher-order factor was less than 0.5 (0.456) due to weak loading (.38) between the ECO value and EBE. In addition, the correlation of the ECO value with other values of EBE was lower than other correlations (Table 2). Given the large sample and number of items, a lower goodness of fit is appropriate. Here, the fit statistics fall within a range of guidelines or good fit (Hair et al., 2018): RMSEA = 0.064; CFI $=0.903 ; \chi 2=1277 ; \mathrm{df}=367 ;$ and $\mathrm{p}<0.001)$. We observed negative high standardized residuals between variables measuring positive and negative well-being (contented/depressed, optimistic/uneasy; enthusiastic/depressed, and contented/gloomy). We discuss this point later.

The direct effects of EBE on negative well-being $(\lambda=0.132 ; p=0.021)$ and positive well-being $(\lambda=0.152 ; p=0.024)$ are significant, but the positive path between EBE and negative well- 
being is counterintuitive (H1a is supported, but H1b is not). ${ }^{7}$ The results also show that EBE has no direct effect on intention to leave $(\lambda=0.034 ; \mathrm{p}=0.467)$. Hypothesis H3 is thus rejected. Positive well-being has a negative effect on intention to leave $(\lambda=-0.391 ; p=0.012)$, while negative well-being has a positive one $(\lambda=0.357 ; p=0.012)$, thus lending support to hypotheses H3a and H3b. All other parameters were statistically significant (see Appendix B). Our results highlight the effects of EBE on positive and negative employee well-being, which, in turn, influence employees' intention to leave.

Due to the unexpected influence of EBE on negative well-being and the weak correlation of the ECO value with the second-order factor, we tested the model after removing the ECO value. In this model, the estimated parameter between EBE and the negative well-being was no longer significant $(\lambda=0.12 ; p=0.06)$.

When considering the mediations between the dimensions of EBE and intention to leave, the results show several significant indirect effects (Table 4). Due to the previous result, we did not consider negative well-being as a mediating variable between EBE and intention to leave.

------ Insert Table 4 about here ------

As expected, the indirect effects of EBE on intention to leave the current employer were all negative when considering positive well-being as a mediating variable: if employees perceive EBE as having a strong application or social value or both, their subjective positive well-being is high, and their intention to leave the employer is low.

\footnotetext{
${ }^{7}$ Complementary analyses were carried out to detect heteroskedasticity. The result of the Beuch-Pagan test is not significant $(\mathrm{p}=0.279)$. Moreover, the QQ plot did not show a clear pattern for residual variances.
} 


\section{Discussion}

\subsection{Theoretical contributions}

The first theoretical contribution concerns the measurement of EBE. Our results confirm the structure of the scale despite major modifications being required and having to eliminate nine of the initial 25 items. In addition, the explained variance (66.4\%) is low for an existing scale, and the AVE is below the expected 0.5 cutoff for the application value. Hair et al. (2017) consider that CFA becomes exploratory when more than $20 \%$ of items are eliminated. As a consequence, economic value is a two-item construct. A minimum of 3 measured indicators is greatly preferable and will minimize the risk of unstable solutions. This study improves the external validity of the EmpAt scale, however, since the scale was used in a different cultural context (France) and with respondents currently in employment (vs. undergraduate students, who were the respondents in the initial study).

We observed some high correlations between standardized residuals (for the well-being measure) and showed that these correlations were not due to common method bias. ${ }^{8}$ One explanation may be a "missing link" between EBE and the two dimensions of well-being. The missing element could be satisfaction at work. Tanwar and Prasad (2016) demonstrated that EBE acts as a critical predictor of job satisfaction. A second explanation may derive from the scale itself. Although Warr's job-related affective well-being measure has been used frequently in the work context, the way the items are structured has seen many variants in previous research. Recently, Laguna, Mielniczuk, Razmus, Moriano, \& Gorgievski (2017) tested different structures for Warr's scale across cultures and genders. The authors found that a 4-factor structure (anxiety, comfort, depression and enthusiasm) performed better than several 2-factor models (positive and negative

\footnotetext{
${ }^{8}$ Thanks to Harman's one-factor test.
} 
well-being; anxiety-comfort and depression-enthusiasm). Considering the results of Laguna and colleagues, we can wonder whether the bipolarity of certain items can explain the high negative correlations of residuals. Warr's scale aims to capture the end points of three axes: anxietycomfort, depression-enthusiasm, and displeased-pleased. Given that Warr's conceptualization of well-being refers to the circumflex framework of emotions (Russell, 1980), high negative correlations between indicators reflecting ending points of underlying axes are not so surprising. We give evidence of the predictive validity of the EmpAt scale, although the effects of the scale on actionable HR variables, such as employee well-being and intention to leave, appear to be complex. EBE influences intention to leave, but this effect is indirect via well-being. More precisely, EBE influences positive well-being, which in turn, negatively influences intention to leave. Contrary to hypothesis H1b, however, the link between EBE and negative well-being is positive. This unexpected result may have several explanations. First, EBE includes various values whose effects on well-being may be conflicting: some dimensions (such as social value) of EBE are socially oriented, while others (such as economic value) are purely self-oriented. In addition, well-being is a subjective perception: the same dimension of EBE may affect individuals differently. Although we expect the influence of high wages on well-being to be generally positive, this influence may be negative for some individuals. A few years ago, Nobel Prize-winning scientists (Kahneman \& Deaton, 2010) found that as income increases, so does life-satisfaction; however, the scientists also showed that this positive effect is not true for emotional well-being, thus giving some scientific support for the popular adage: "money cannot buy happiness". Our research is consistent with that of Kahneman and Deaton and shows that "an attractive overall compensation package" and "an above average basic salary" can lead to negative well-being at work. In the early 2000s, Cable and Turban (2003) found that "individuals 
were willing to pay premium in the form of lower wages to join firms with a positive reputation" (p. 2251), just as consumers will pay more for a prestigious brand (Park \& Srinivasan, 1994). This unexpected relationship between EBE and negative well-being may be due to a generation effect. As emphasized by Miller (2018), for Gen Y, job interest is more important than financial stability. The respondents in this study were from different generations, but $31 \%$ of the respondents were from Gen Y.

Our results show an indirect effect of EBE on an intention to leave a job. This influence is negative via positive well-being. Three mediating effects are confirmed. These mediating effects are due to the application, social, and interest values of EBE. If an employee perceives that the employer brand offers an interesting job (interest value), supportive and encouraging colleagues (social value), and the opportunity to apply and share what was learned (application value), he or she experiences positive well-being and has no intention of seeking a new job. A strong EBE may reduce the risk of high staff turnover because of positive well-being enhancement. This result is consistent with marketing literature linking brand equity to brand loyalty (Juntunen, Juntunen, \& Juga, 2011; Taylor et al., 2004).

In conclusion, our results confirm the explanatory power of the EmpAt scale and establish direct effects on positive well-being and indirect effects on intention to leave the current job.

\subsection{Practical contributions}

Our results show that the influence of EBE on the behavioral intentions of employees is relatively complex. It would be very useful, however, for HR managers to better understand the conditions in which positive EBE effects on loyalty intention outweigh the negative ones.

We can question whether the EmpAt scale is recommended for HR managers. Although the tool has the merit of embracing the concept of EBE fairly precisely, the tool still suffers from 
weaknesses. First, despite the elimination of items, the length of this scale makes it unwieldy for HR managers. A more synthetic measurement tool, with 3 items per dimension, would probably be more practical. Second, the EmpAt scale does not consider the sustainability of the employer brand. Recently, Tanwar and Prasad (2016) successfully added a corporate social responsibility dimension to EBE.

Although the issue of the measurement of EBE still persists, our results indicate that the EBE concept is obviously useful from a managerial perspective because EBE can increase positive employee well-being at work and reduce staff turnover. Companies have a real interest in investing in their EBE. While the focus of past research was mainly on the external attractiveness of EBE, our results emphasize the retention power of EBE inside the organization. To strengthen their EBE, companies must ensure that HR practices are consistent with their EB. In so doing, the internal and external images of the EB will be congruent, thus making the company attractive to potential candidates and ensuring the loyalty of current employees.

\subsection{Limitations and further research}

The EBE measurement scale needs improvement to gain stability and practicality. One limitation, which is also an interesting research avenue, is related to the measurement of economic value. After CFA, only two items directly related to the economic aspect (basic salary and remuneration) of EBE were kept. The other three items, discarded during PCA and CFA, measured various aspects that do not reflect only economic value: "Good promotion opportunities within the organization," "Job security within the organization," and "Hands-on interdepartmental experience". These items may relate to economic safety to varying degrees, but these items also include a broader safety dimension. Further research is required to identify items that more accurately reflect the economic value associated with EBE. 
A second weakness is that the EmpAt scale does not clearly reflect CSR value. The context has changed since the early 2000s. Consumers are now more sensitive to brands' CSR arguments. Through a halo effect, this CSR sensitivity could be generalized to EB. In recent research (Authors, 2017), some items of the application value (EBE16; EBE17; EBE18) and the economic value (EBE21; EBE22) reflected a common factor, which we described as a sustainable commitment by the EB; sustainable commitment by the EB requires further investigation and can enrich the EmpAt scale.

Employees' perception of HR practices (HR attributions) can also improve the model. Nishii, Lepak, and Schneider (2008, p. 9) define HR attributions as "causal explanations that employees make regarding management's motivations for using particular HR practices" and emphasize the importance of these practices for employees' attitudes.

Aaker, D. A. (1991). Managing Brand Equity: Capitalizing on the Value of the Brand Name. New York: The Free Press.

Ambler, T., \& Barrow, S. (1996). The employer brand. Journal of Brand Management, 4(3), 185-206. https://doi.org/10.1057/bm.1996.42.

Anderson, J. C., \& Gerbing, D. W. (1988). Structural Modeling in practice: a review and recommended two steps approach. Psychological Bulletin, 103(3), 411-423. https://doi.org/10.1037/0033-2909.103.3.411.

Arachchige, B. J. H., \& Robertson, A. (2011). Business student perceptions of a preferred employer: A study identifying determinants of employer branding. The IUP Journal of Brand Management, 8(3), 25-46.

Aureliano-Silva, L., Strehlau, S., \& Strehlau, V. (2018). The relationship between brand 
attachment and consumers' emotional well-being. Journal of the Relationship Marketing, 17(1), 1-16. https://doi.org/10.1080/15332667.2017.1391058.

Benraïss-Noailles, L., \& Viot, C. (2017). Attractivité des entreprises low-cost: le rôle du CapitalMarque Employeur. Revue Française de Gestion, 266(5), 89-109. https://doi.org/10.3166/rfg.2017.00159

Berthon, P., Ewing, M., \& Hah, L. (2005). Captivating company: Dimensions of attractiveness in employer branding. International Journal of Advertising, 24(2), 151-172. https://doi.org/10.4236/acs.2013.34049.

Bigliardi, B., Petroni, A., \& Ivo Dormio, A. (2005). Organizational socialization, career aspirations and turnover intentions among design engineers. Leadership \& Organization Development Journal, 26(6), 424-441. DOI:10.1108/01437730510617645.

Biswas, M. K., \& Suar, D. (2016). Antecedents and consequences of employer branding. Journal of Business Ethics, 136(1), 57-72. https://doi.org/10.4102/sajhrm.v9i1.388.

Cable D. M., \& Turban D. B. (2003). The value of organizational reputation in the recruitment context: A brand-equity perspective. Journal of applied social psychology, 33(11), 2244-2266, https://doi.org/10.1111/j.1559-1816.2003.tb01883.x.

Cho, S., Johanson, M. M., \& Guchait, P. (2009). Employees intent to leave: A comparison of determinants of intent to leave versus intent to stay. International Journal of Hospitality Management, 28(3), 374-381. https://doi.org/10.1016/j.ijhm.2008.10.007.

Ewing M., Pitt L., de Bussy N., \& Berthon P. (2002). Employment branding in the knowledge economy. International Journal of Advertising, 21(1), 3-22. https://doi.org/ 10.1080/02650487.2002.11104914.

Evanschitzky, H., \& Armstrong, J. S. (2013). Research with In-built replications: Comment and 
further suggestions for replication research. Journal of Business Research,66(9), 1406-1408. https://doi.org/10.1016/j.jbusres.2012.05.006.

Fornell, C., \& Larcker, D. F. (1981). Evaluating structural equation models with unobservable variables and measurement error. Journal of Marketing Research, 18(1), 39-50. https://doi.org/10.2307/3151312.

Foster, C., Punjaisri, K., \& Cheng, R. (2010). Exploring the relationship between corporate, internal and employer branding, Journal of Product \& Brand Management, 19(6), 401-409. https://doi.org/10.1108/10610421011085712.

Franca V., \& Pahor M. (2012). The Strength of the employer brand: influences and implications for recruiting. Journal of Marketing and Management, 3(1), 78-122. https://doi.org/10.1515/eb2015-0009.

Fuller, C. M., Simmering M. J., Atinc G. Atinc Y., \& Babin B. J. (2016). Common methods variance detection in business research, Journal of Business Research, 69 (8), 3192-3198. https://doi.org/10.1016/j.jbusres.2015.12.008.

Giraud, L. (2015). L'intention de quitter l'entreprise : une approche par l'étape de carrière. Revue de Gestion des Ressources Humaines, 3(97), 58-86. DOI:10.3917/grhu.097.0058.

Gorge, H., Özçaglar-Toulouse, N., \& Toussaint, S. (2015). Bien-être and well-being in consumer research: A comparative analysis. Recherche et Applications en Marketing, 30(2), 104-123. https://doi.org/10.1177/2051570715579411.

Guerrero, S., \& Herrbach, O. (2009). La confiance organisationnelle au cœur de l'échange social: et si bien traiter ses employés était payant? Relations industrielles/Industrial Relations, 64(1), 6-26. https://doi.org/10.7202/029536ar.

Hair, J. F., Babin, B. J.; \& Krey, N. (2017). Covariance-based structural equation modeling in 
the Journal of Advertising: Review and recommendations. Journal of Advertising, 46(1), 1-15. https://doi.org/10.1080/00913367.2017.1281777.

Hair, J.F.; Black, W.C., Babin, B.J. and Anderson, R.E. (2018). Multivariate data analysis. 8th Edition, Cengage.

Hubbard, R., \& Amstrong, J. S. (1994). Replications and extensions in marketing: Rarely published but quite contrary. International Journal of Research in Marketing, 11(3), 233-248. https://doi.org/10.1016/0167-8116(94)90003-5.

Jiang, T., \& Iles, P. (2011). Employer-brand equity, organizational attractiveness and talent management in the Zhejiang private sector, China. Journal of Technology Management in China, 6(1), 97-110. https://doi.org/10.1108/17468771111105686.

Juntunen, M., Juntunen, J., \& Juga, J. (2011). Corporate brand equity and loyalty in B2B markets: A study among logistics service purchasers. Journal of Brand Management, 18(4/5), 300-311. https://doi.org/10.1057/bm.2010.43.

Kahneman, D., \& Deaton, A. (2010). High income improves evaluation of life but not emotional well-being. Proceedings of the National Academy of Science of the United States of America, 107(38), 16489-16493. https://doi.org/10.1073/pnas.1011492107.

Keller, K. L. (1993). Conceptualizing, measuring and managing customer-based brand equity. Journal of Marketing, 57(1), 1-22. https://doi.org/10.2307/1252054.

Kima, K. H.; Jeon, B. J.; Jung, H. S.; Lub, W., \& Jones, J. (2011). Effective employment brand equity through sustainable competitive advantage, marketing strategy, and corporate image. Journal of Business Research, 64(11), 1207-1211. https://doi.org/10.1016/j.jbusres.2011.02.047. Laguna, M., Mielniczuk, E., Razmus, W., Moriano, J. A.,\& Gorgievski, M. J. (2017). Crossculture and gender invariance of the Warr (1990) job-related well-being measure. Journal of 
Occupational and Organizational Psychology, 90(1), 117-125.

https://doi.org/10.1111/joop.12166.

Lee, C. C., Kao, R. H., \& Lin, C. J. (2018). A study on the factors to measure employer brand: the case of undergraduate senior students. Chinese Management Studies, 12(4), 812-832. https://doi.org/10.1108/CMS-04-2017-0092.

Liua, G., Ko, W. W., \& Chapleo, C. (2017). Managing employee attention and internal branding. Journal of Business Research, 79, 1-11. https://doi.org/10.1016/j.jbusres.2017.05.021.

Logan, G. M. (1984). Loyalty and a sense of purpose. California Management Review, 27(1), 149-156. https://doi.org/10.2307/41165119.

Miller J. (2018). A 16-year-old explains 10 things you need to know about generation Z, Human Resources Magazine, November/December, online https://www.shrm.org/hr-today/news/hrmagazine/1118/pages/a-16-year-old-explains-10-things-you-need-to-know-about-generationZ.aspx

Mitchell, T. R., \& Lee, T. W. (2001). The unfolding model of voluntary turnover and job embeddedness: Foundations for a comprehensive theory of attachment. Research in Organizational Behavior, 23, 189-246. https://doi.org/10.1016/S0191-3085(01)23006-8.

Moore, J. E. (2000). One road to turnover: An examination of work exhaustion in technology professionals. MIS Quarterly, 24(1), 141-168. https://doi.org/10.2307/3250982.

Morrell, K. (2005). Towards a typology of nursing turnover: the role of shocks in nurses' decisions to leave. Journal of Advanced Nursing, 49(3), 315-322. https://doi.org/10.1111/j.13652648.2004.03290.x.

Mowday, R. T., Porter, L. W., \& Steers, R. M. (1982). Employee-organization linkage. The psychology of commitment absenteism, and turn over. London: Academic Press Inc. 
Nishii, L. H., Lepak, D. P., \& Schneider, B. (2008). Employee attributions of the "why" of HR practices: their effects on employee attitudes and behaviors, and customer satisfaction. Personnel Psychology, 61(3), 503-545. https://doi.org/10.1111/j.1744-6570.2008.00121.x.

Oliver, R. L. (1999). Whence consumer loyalty? Journal of Marketing, 63, 33-44. https://doi.org/10.2307/1252099.

Panczuk, S., \& Point, S. (2011). Enjeux et outils du marketing RH: promouvoir et vendre les ressources humaines. Paris: Eyrolles.

Park, C. S., \& Srinivasan, V. (1994). A survey-based method for measuring and understanding brand equity and its extendibility. Journal of Marketing Research, 31, 271-288. https://doi.org/10.2307/3152199.

Podsakoff, P. M., \& Organ, D. W. (1986). Self-reports in organizational research: Problems and prospects. Journal of Management, 12, 69-82. https://doi.org/10.1177/014920638601200408.

Roy, S. K. (2008). Identifying the dimensions of attractiveness of an employer branding: the Indian context. South Asian Journal of Management, 15(4), 111-130.

Russell, J. A. (1980). A circumplex model of affect. Journal of Personality and Social Psychology, 39, 1169-1178.

Sevastos, P., Smith, L., \& Cordery, J.L. (1992). Evidence on the reliability and construct validity of Warr's (1990) well-being and mental health measures. Journal of Occupational and Organizational Psychology, 65(1), 33-49. https://doi.org/10.1111/j.2044-8325.1992.tb00482.x.

Sharma, R., \& Prasad, A. (2018). Employer Brand and Its External Perspective. In In: D. S. Sushil (Eds.), Flexible Strategies in VUCA Markets. Flexible Systems Management (pp. 251268). Singapore: Springer. https://doi.org/10.1007/978-981-10-8926-8_19.

Soulez, S., \& Guillot-Soulez, C. (2011). Marketing de recrutement et segmentation 
générationnelle: regard critique à partir d'un sous-segment de la génération Y. Recherche et Applications en Marketing, 26(1), 39-57. https://doi.org/10.1177/076737011102600103.

Tanwar, K., \& Prasad, A. (2016). The effect of employer brand dimensions on job satisfaction: gender as a moderator. Management Decision, 54(4), 854-886. https://doi.org/10.1108/MD-082015-0343.

Taylor, S. A., Celuch K., \& Goodwin S. (2004). The importance of brand equity to customer loyalty. Journal of Product \& Brand Management, 13(4), 217-227. https://doi.org/10.1108/10610420410546934.

Troebs, C.-C., Wagner, T., \& Heideman, F. (2018). Transformative retail services: Elevating loyalty through customer well-being. Journal of Retailing and Consumer Services, 45, 198-206. https://doi.org/10.1016/j.jretconser.2018.09.009.

Viot, C., \& Benraïss-Noailles, L. (2019). The link between benevolence and well-being in the context of human-resource marketing. Journal of Business Ethics, 159(3), 883-896.

https://doi.org/10.1007/s10551-018-3834-1

Warr, P. (1990). The measurement of well-being and other aspects of mental health. Journal of Occupational Psychology, 63(3), 193-210. https://doi.org/10.1111/j.2044-8325.1990.tb00521.x. Wright, T. A., \& Bonett, D. G. (2007). Job satisfaction and psychological well-being as nonadditive predictors of workplace turnover. Journal of Management, 33(2), 141-160. https://doi.org/10.1177/0149206306297582. 
Appendix A. Means, standard deviations, and correlations

"Table joined in a separate file" 


\section{Appendix B. Causal model}

\begin{tabular}{|c|c|c|c|c|}
\hline \multicolumn{4}{|c|}{ Parameter } & \multirow{2}{*}{$\begin{array}{l}\text { Parameter } \\
0.152^{*}\end{array}$} \\
\hline Structural paths & PWB & $<---$ & EBE & \\
\hline & NWB & $<---$ & $\mathrm{EBE}$ & $0.132 *$ \\
\hline & INT & $<---$ & $\mathrm{EBE}$ & $0.696^{* *}$ \\
\hline & DEV & $<---$ & $\mathrm{EBE}$ & $0.744 * *$ \\
\hline & SOC & $<---$ & EBE & $0.717 *$ \\
\hline & APPLI & $<---$ & EBE & $0.765^{*}$ \\
\hline & $\mathrm{ECO}$ & $<---$ & EBE & $0.382^{* *}$ \\
\hline & IL & $<---$ & PWB & $-0.391 *$ \\
\hline & IL & $<---$ & NWB & $0.357^{*}$ \\
\hline & IL & $<---$ & EBE & 0.034 \\
\hline \multirow[t]{4}{*}{ Interest value } & EBE14 & $<--$ & INT & $0.736^{*}$ \\
\hline & EBE13 & $<---$ & INT & $0.629 *$ \\
\hline & EBE12 & $<---$ & INT & $0.754^{*}$ \\
\hline & EBE11 & $<---$ & INT & $0.838^{*}$ \\
\hline \multirow[t]{3}{*}{ Development value } & EBE6 & $\begin{array}{ll}<-- \\
\end{array}$ & DEV & $0.598^{*}$ \\
\hline & EBE5 & $<---$ & DEV & $0.837 * *$ \\
\hline & EBE4 & $<--$ & DEV & $0.736^{*}$ \\
\hline \multirow[t]{4}{*}{ Social value } & EBE23 & $<--$ & SOC & $0.642^{*}$ \\
\hline & EBE9 & $<---$ & SOC & $0.778 * *$ \\
\hline & EBE8 & $<---$ & SOC & $0.850^{*}$ \\
\hline & EBE7 & $<---$ & SOC & $0.710^{*}$ \\
\hline \multirow[t]{3}{*}{ Application value } & EBE19 & $<--$ & APPLI & $0.611^{* *}$ \\
\hline & EBE18 & $<---$ & APPLI & $0.762^{*}$ \\
\hline & EBE17 & $<--$ & APPLI & $0.651^{*}$ \\
\hline \multirow[t]{2}{*}{ Economic value } & EBE24 & $<--$ & ECO & $0.876^{*}$ \\
\hline & EBE25 & $<---$ & $\mathrm{ECO}$ & $0.835^{*}$ \\
\hline \multirow[t]{5}{*}{ Positive well-being } & WB8 & $<--$ & PWB & $0.795^{*}$ \\
\hline & WB9 & $<---$ & PWB & $0.816^{*}$ \\
\hline & WB10 & $<--$ & PWB & $0.893^{*}$ \\
\hline & WB11 & $<---$ & PWB & $0.788^{*}$ \\
\hline & WB12 & $<--$ & PWB & $0.795^{*}$ \\
\hline \multirow[t]{4}{*}{ Negative well-being } & WB2 & $<--$ & NWB & $0.807 *$ \\
\hline & WB6 & $<---$ & NWB & $0.815^{*}$ \\
\hline & WB5 & $<--$ & NWB & $0.885^{*}$ \\
\hline & WB4 & $<---$ & NWB & $0.787^{*}$ \\
\hline \multirow[t]{4}{*}{ Intention to leave } & IL1 & $<--$ & $\mathrm{IL}$ & $0.928^{*}$ \\
\hline & IL2 & $<---$ & IL & $0.938^{*}$ \\
\hline & IL3_INV & $<---$ & IL & $0.801^{*}$ \\
\hline & IL4_INV & $<---$ & IL & $0.776^{* *}$ \\
\hline
\end{tabular}

Note:

* Coefficient is significant at the 0.05 level (2-tailed).

$* * *$ Coefficient is significant at the 0.01 level (2-tailed). 


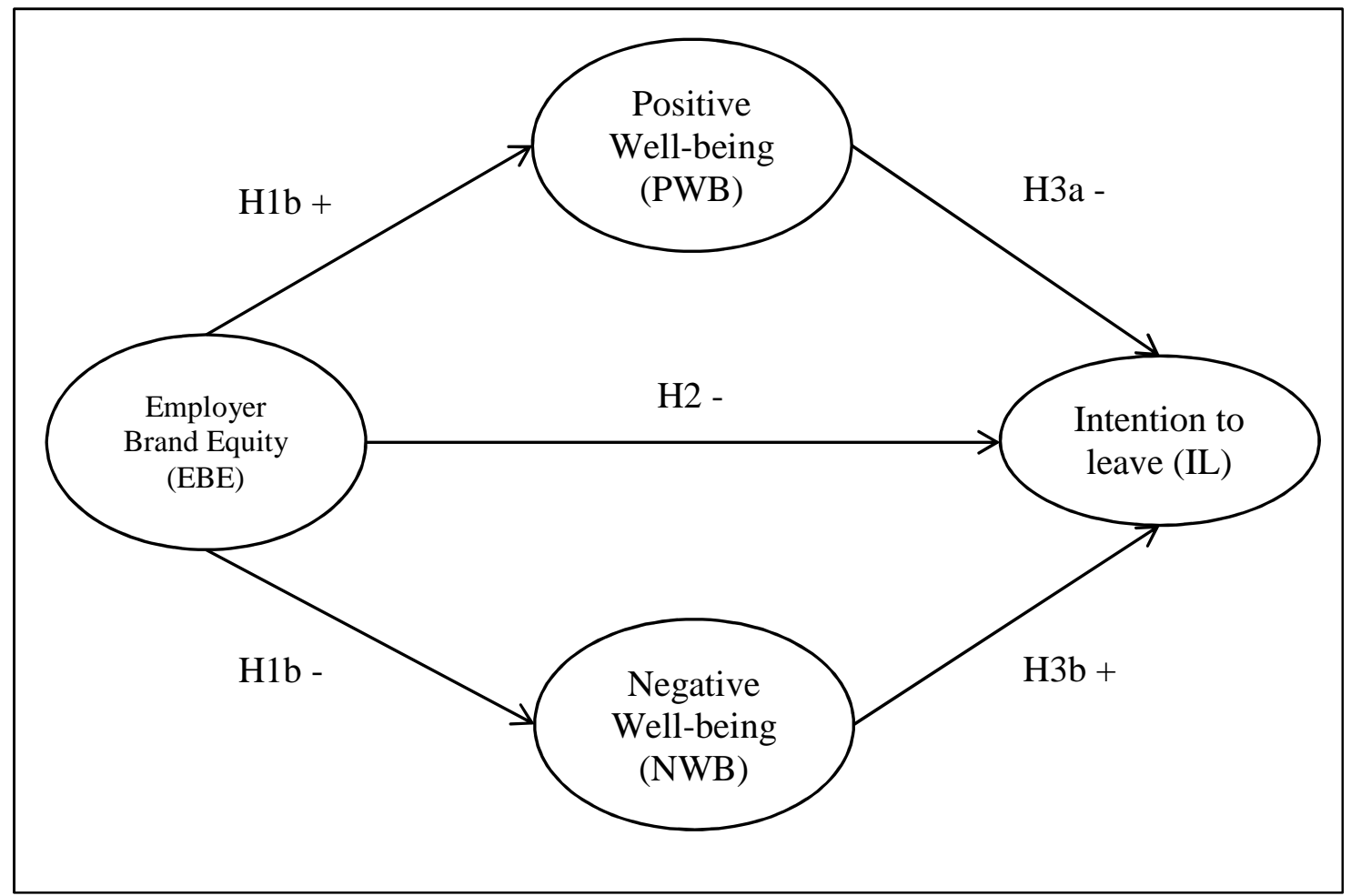

Fig. 1. Conceptual model and hypothesis 
Table 1

Measurement scales and CFA results.

\begin{tabular}{|c|c|c|c|}
\hline Scales & & Structure and number of items & Confirmatory factor analysis \\
\hline \multirow{5}{*}{$\begin{array}{l}\text { EmpAt } \\
\text { Berthon et } \\
\text { al. (2005) }\end{array}$} & \multirow{5}{*}{$\begin{array}{l}\text { Social value } \\
(\mathrm{SOC})\end{array}$} & EBE2. A fun working environment & $r$ \\
\hline & & EBE7. Having a good relationship with your superiors & $0.712 *$ \\
\hline & & EBE8. Having a good relationship with your colleagues & $0.847 *$ \\
\hline & & EBE9. Supportive and encouraging colleagues & $0.778 *$ \\
\hline & & EBE23. Happy work environment & $0.643^{*}$ \\
\hline \multirow{2}{*}{$\begin{array}{l}\text { Used by: } \\
\text { Roy (2008) }\end{array}$} & \multirow{5}{*}{$\begin{array}{l}\text { Interest value } \\
\text { (INT) }\end{array}$} & EBE10. Working in an exciting environment & $r$ \\
\hline & & EBE11. Innovative employer - novel work practices/forward thinking & $0.835^{*}$ \\
\hline \multirow{2}{*}{$\begin{array}{l}\text { Arachchige \& } \\
\text { Robertson } \\
(2011)\end{array}$} & & EBE12. The organization both values and makes use of your creativity & $0.753^{*}$ \\
\hline & & EBE13. The organization produces high-quality products and services & $0.632 *$ \\
\hline \multirow{2}{*}{$\begin{array}{l}\text { Jiang \& Iles } \\
(2011)\end{array}$} & & EBE14. The organization produces innovative products and services & $0.738 *$ \\
\hline & \multirow{5}{*}{$\begin{array}{l}\text { Development } \\
\text { value }(\mathrm{DEV})\end{array}$} & EBE1. Recognition/appreciation from management & $r$ \\
\hline $\begin{array}{l}\text { Authors } \\
\text { (2017) }\end{array}$ & & EBE3. A springboard for future employment & $r$ \\
\hline $\begin{array}{l}\text { Biswas \& } \\
\text { Suar (2016) }\end{array}$ & & $\begin{array}{l}\text { EBE4. Feeling good about yourself as a result of working for a particular } \\
\text { organization }\end{array}$ & $\begin{array}{l}0.742 * \\
0.834 * *\end{array}$ \\
\hline $\begin{array}{l}\text { Sharma \& } \\
\text { Prasad (2018) }\end{array}$ & & $\begin{array}{l}\text { EBE5. Feeling more self-confident as a result of working for a particular } \\
\text { organization }\end{array}$ & $0.593 * *$ \\
\hline \multirow{7}{*}{$\begin{array}{l}\text { Lee, Kao \& } \\
\text { Lin }(2018)\end{array}$} & & EBE6. Gaining career-enhancing experience & \\
\hline & \multirow{5}{*}{$\begin{array}{l}\text { Application } \\
\text { value (APP) }\end{array}$} & EBE17. Opportunity to apply what was learned at a tertiary institution & $0.651^{*}$ \\
\hline & & EBE18. Opportunity to teach others what you have learned & $0.776^{*}$ \\
\hline & & EBE19. Acceptance and belonging & $0.599 *$ \\
\hline & & EBE20. The organization is customer oriented & $r$ \\
\hline & & EBE16. A socially responsible organization & $r$ \\
\hline & $\begin{array}{l}\text { Economic } \\
\text { value }(\mathrm{ECO})\end{array}$ & EBE15. Good promotion opportunities within the organization & $r$ \\
\hline
\end{tabular}




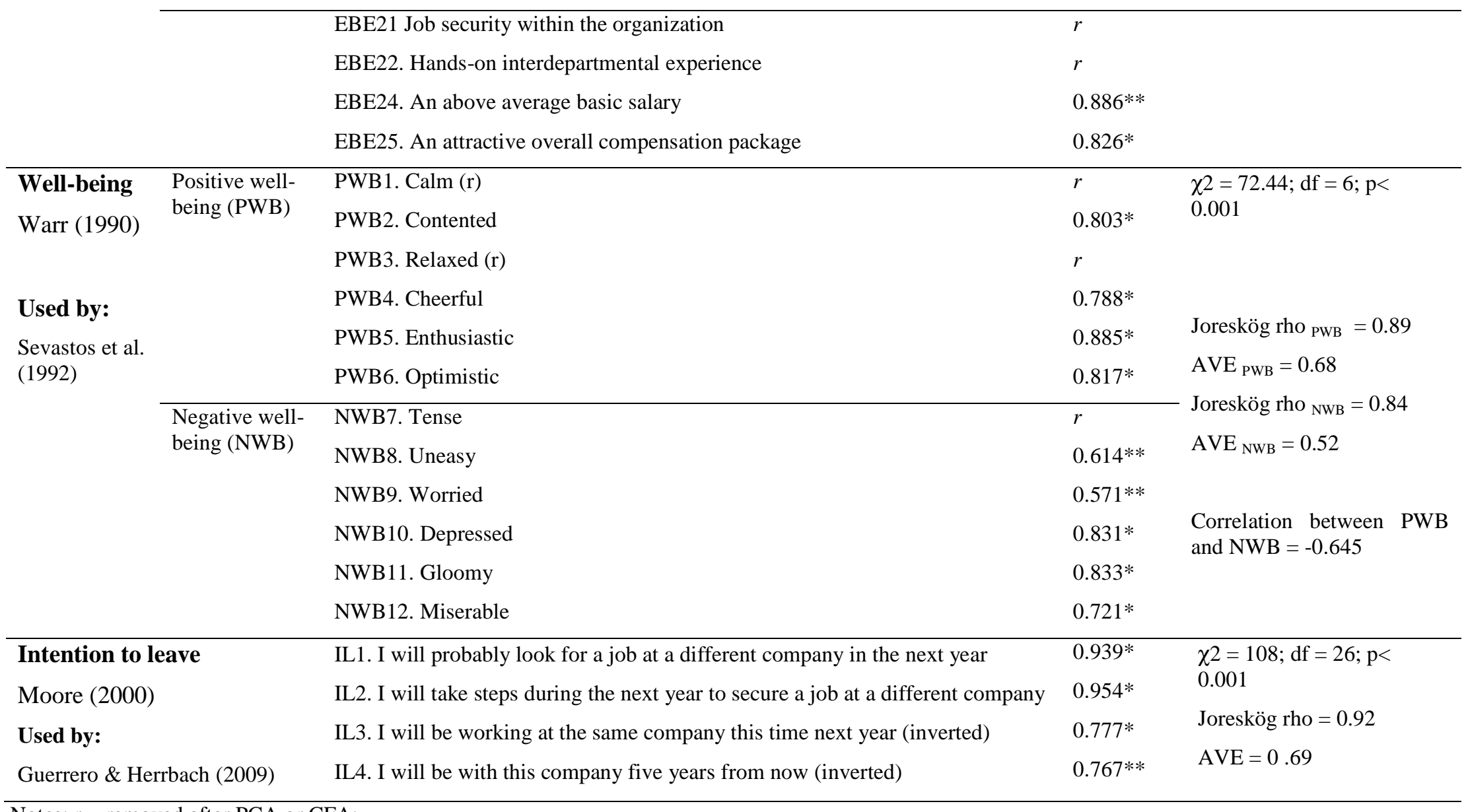

Notes: $r=$ removed after PCA or CFA;

Discriminant validity of well-being: the square correlation between PWB and NWB (0.422) is below the AVE of each dimension of well-being: 0.68 for PWB, and 0.52 for NWB.

* Coefficient is significant at the 0.05 level (2-tailed).

*** Coefficient is significant at the 0.01 level (2-tailed) 
Table 2

Employer Brand Equity discriminant validity.

\begin{tabular}{lcccccc}
\hline & 1 & 2 & 3 & 4 & 5 & Joreskög rho \\
\hline 1. Interest value & $\mathbf{0 . 5 5}$ & & & & & 0.83 \\
\hline 2. Social value & 0.22 & $\mathbf{0 . 7 2}$ & & & & 0.83 \\
\hline 3. Development value & 0.24 & 0.34 & $\mathbf{0 . 5 3}$ & & & 0.77 \\
\hline 4. Application value & 0.37 & 0.26 & 0.28 & $\mathbf{0 . 4 9}$ & & 0.74 \\
\hline 5. Economics value & 0.06 & 0.09 & 0.08 & 0.07 & $\mathbf{0 . 7 3}$ & 0.85 \\
\hline
\end{tabular}

Notes: Values on the main diagonal (in bold) are the average variance extracted (AVE); values below the diagonal are squared correlations. 


\section{Table 3}

Means and standard deviations of means scores for latent constructs.

\begin{tabular}{lll}
\hline & Mean score & Standard deviation \\
\hline Negative well-being & 2.19 & 0.88 \\
Positive well-being & 3.57 & 1.02 \\
\hline Employer brand equity & 4.75 & 0.56 \\
$\quad$ Interest value & 4.74 & 0.78 \\
$\quad$ Social value & 4.95 & 0.68 \\
$\quad$ Application value & 4.64 & 0.71 \\
$\quad$ Development value & 4.71 & 0.80 \\
$\quad$ Economic value & 4.67 & 0.93 \\
\hline Intention to leave the employer & 3.20 & 1.49
\end{tabular}

Notes: (1) Mean score for latent constructs $=$ summed of the mean score of items/number of items 


\section{Table 4}

Results of parallel mediation analyses.

\begin{tabular}{llll}
\hline & Direct effects & Indirect effects & Total effect \\
\hline $\mathrm{INT} \rightarrow \mathrm{PWB} \rightarrow \mathrm{IL}$ & $\mathrm{ns}$ & $-0.09^{*}$ & $\mathrm{~ns}$ \\
$\mathrm{APP} \rightarrow \mathrm{PWB} \rightarrow \mathrm{IL}$ & $\mathrm{ns}$ & $-0.05^{*}$ & $\mathrm{~ns}$ \\
$\mathrm{DEV} \rightarrow \mathrm{PWB} \rightarrow \mathrm{IL}$ & $\mathrm{ns}$ & $\mathrm{ns}$ & $\mathrm{ns}$ \\
$\mathrm{SOC} \rightarrow \mathrm{PWB} \rightarrow \mathrm{IL}$ & $\mathrm{ns}$ & $-0.06^{*}$ & $\mathrm{~ns}$ \\
$\mathrm{ECO} \rightarrow \mathrm{PWB} \rightarrow \mathrm{IL}$ & $\mathrm{ns}$ & $\mathrm{ns}$ &
\end{tabular}

Notes: Standardized coefficients are reported; number of bootstrap samples: 5000; ns means coefficient is not significant; and mediations were tested with the macro Process model 4.

* Coefficient is significant at the 0.05 level (2-tailed). 


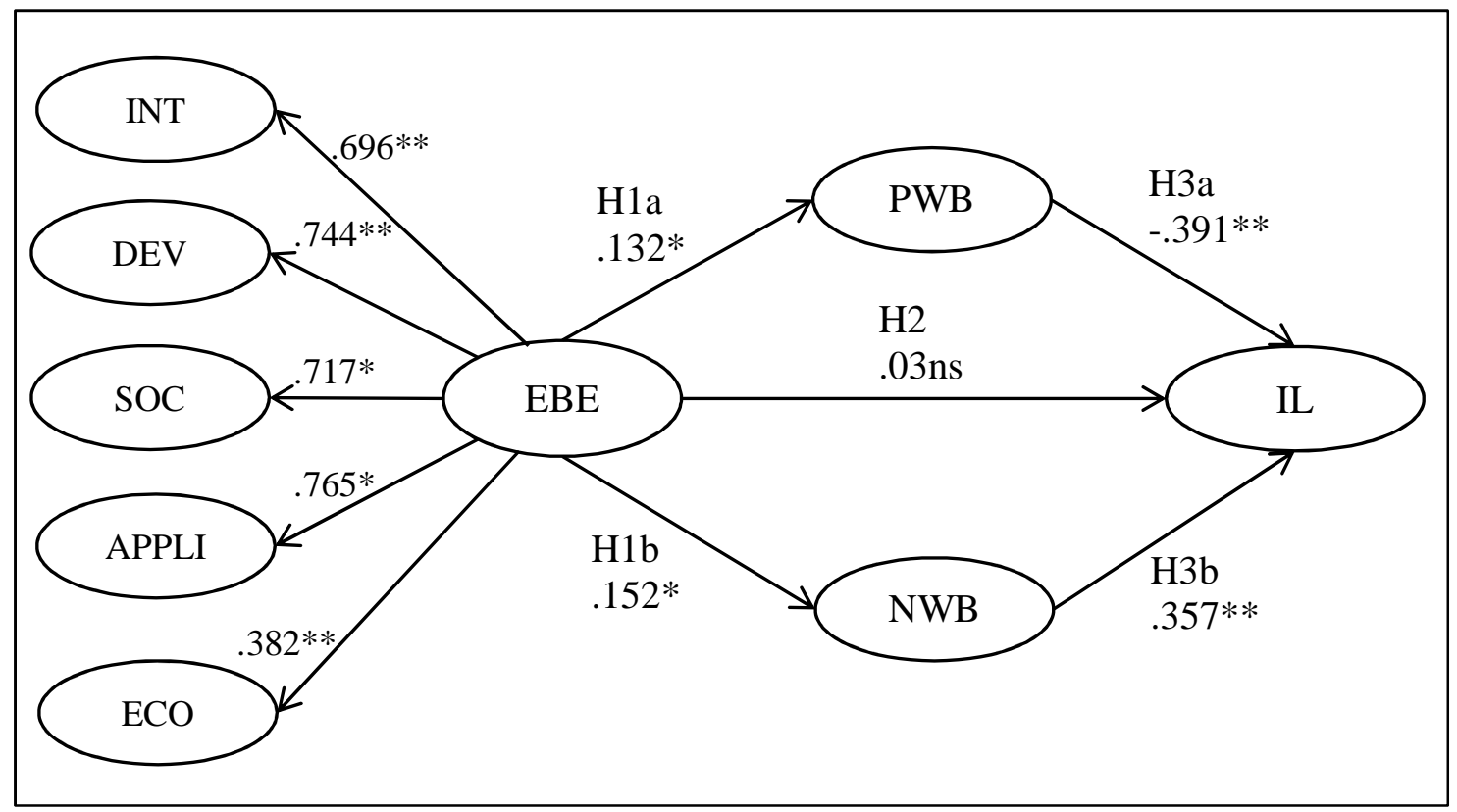

Fig. 2. Causal model with EBE considered as a second-order factor. 